Published in final edited form as:

Addict Behav. 2014 February ; 39(2): 406-413. doi:10.1016/j.addbeh.2013.08.024.

\title{
Alcohol Misuse and Psychological Resilience among U.S. Iraq and Afghanistan Era Veteran Military Personnel
}

\author{
Kimberly T. Green, \\ Duke University Medical Center, Durham, North Carolina, USA
}

Jean C. Beckham, Department of Veterans Affairs Medical Center, Durham, North Carolina, USA. Duke University Medical Center, Durham, North Carolina, USA. VA Mid-Atlantic Mental Illness Research, Education and Clinical Center, Durham, NC USA

Nagy Youssef, and Duke University Medical Center, Durham, North Carolina, USA. University of South Alabama, Mobile, Alabama, USA

Eric B. Elbogen

University of North Carolina Chapel-Hill, Chapel-Hill, North Carolina, USA. VA Mid-Atlantic Mental Illness Research, Education and Clinical Center, Durham, NC USA

\section{Abstract}

Objective-The present study sought to investigate the longitudinal effects of psychological resilience against alcohol misuse adjusting for socio-demographic factors, trauma-related variables, and self-reported history of alcohol abuse.

\begin{abstract}
Methodology—Data were from National Post-Deployment Adjustment Study (NPDAS) participants who completed both a baseline and one-year follow-up survey $(\mathrm{N}=1090)$. Survey questionnaires measured combat exposure, probable posttraumatic stress disorder (PTSD), psychological resilience, and alcohol misuse, all of which were measured at two discrete time periods (baseline and one-year follow-up). Baseline resilience and change in resilience (increased
\end{abstract}

\footnotetext{
(C) 2013 Elsevier Ltd. All rights reserved.

Correspondence concerning this article should be addressed to Kimberly Green, M.S., 508 Fulton Drive, Building \#16, Room 62, Durham, North Carolina 27705, Phone: (919) 286-0411 x. 7093, kimberly.green@duke.edu.

Kimberly T. Green, Department of Psychiatry and Behavioral Sciences, Duke University Medical Center; Nagy Youssef, Department of Psychiatry and Behavioral Services, Duke University Medical Center, Durham, North Carolina, USA, University of South

Alabama, Mobile, Alabama, USA; Jean C. Beckham, Department of Veterans Affairs Medical Center, Durham, North Carolina, USA, Department of Psychiatry and Behavioral Sciences, Duke University Medical Center, Durham, North Carolina, USA, VA MidAtlantic Mental Illness Research, Education and Clinical Center, Durham, NC USA; Eric B. Elbogen, Department of Psychiatry, University of North Carolina Chapel-Hill, Chapel-Hill, North Carolina, USA, VA Mid-Atlantic Mental Illness Research, Education and Clinical Center, Durham, NC USA
}

\section{Contributors}

Ms. Green wrote the first version of the manuscript. Dr. Youssef participated in edits of the manuscript. Dr. Beckham participated in the conceptualization and writing of the manuscript. Dr. Elbogen contributed to each aspect of this project from study design to edits of the manuscript. All authors have approved the final manuscript.

\section{Conflict of Interest}

My coauthors, Drs. Youssef, Beckham, and Elbogen and I do not have any interests that might be interpreted as influencing the research. APA ethical standards were followed in the conduct of this research.

Publisher's Disclaimer: This is a PDF file of an unedited manuscript that has been accepted for publication. As a service to our customers we are providing this early version of the manuscript. The manuscript will undergo copyediting, typesetting, and review of the resulting proof before it is published in its final citable form. Please note that during the production process errors may be discovered which could affect the content, and all legal disclaimers that apply to the journal pertain. 
or decreased) were utilized as independent variables in separate models evaluating alcohol misuse at the one-year follow-up.

Results-Multiple linear regression analyses controlled for age, gender, level of educational attainment, combat exposure, PTSD symptom severity, and self-reported alcohol abuse. Accounting for these covariates, findings revealed that lower baseline resilience, younger age, male gender, and self-reported alcohol abuse were related to alcohol misuse at the one-year follow-up. A separate regression analysis, adjusting for the same covariates, revealed a relationship between change in resilience (from baseline to the one-year follow-up) and alcohol misuse at the one-year follow-up. The regression model evaluating these variables in a subset of the sample in which all the participants had been deployed to Iraq and/or Afghanistan was consistent with findings involving the overall era sample. Finally, logistic regression analyses of the one-year follow-up data yielded similar results to the baseline and resilience change models.

Conclusions-These findings suggest that increased psychological resilience is inversely related to alcohol misuse and is protective against alcohol misuse over time. Additionally, it supports the conceptualization of resilience as a process which evolves over time. Moreover, our results underscore the importance of assessing resilience as part of alcohol use screening for preventing alcohol misuse in Iraq and Afghanistan era military veterans.

\section{Keywords}

Substance Misuse; Resilience; Military Veterans

\section{Introduction}

Alcohol misuse in the U.S. military is widespread (Institute of Medicine, 2013; Ames \& Cunradi, 2004). Current population estimates range from $22 \%$ to $40 \%$, a considerable higher rate when compared to non-military populations (Eisen et al., 2012; Seal et al., 2011; Calhoun et al., 2008). Although previous studies have attempted to clarify the rates of alcohol misuse in military samples, less attention has been placed on identifying protective mechanisms that buffer against high risk drinking in this population (Scott et al., 2012). Longitudinal assessment using standardized measures in the same sample could lead to a more complete understanding of the course of alcohol misuse and potential protective factors among U.S. Iraq/Afghanistan era servicemembers.

\section{Characterizing Alcohol Misuse}

Alcohol misuse is a collective term for defining problems or conditions related to alcohol use. More specifically, it refers to any alcohol drinking behavior that increases an individual's risk for negative health and social consequences (U.S. Department of Health and Human Services, 2005). While repeated alcohol misuse has been linked to dependence, not all high-risk drinkers become dependent users (Babor et al., 2001) - suggestive of a protective mechanism at play. Further study of the mechanisms important for protection against alcohol misuse is needed for understanding the extent in which these mechanisms buffer against problem alcohol drinking in U.S. Iraq and Afghanistan Era Veterans.

\section{Combat Exposure, PTSD, and Socio-demographic Variables: Documented Risks of Alcohol Misuse}

Combat exposure is a risk factor for a number of psychological conditions including alcohol misuse (Hoge, Auchterlonie, \& Milliken, 2006; Bray \& Hourani, 2007; Schlenger et al., 2007; Kulka et al., 1990b; Marx et al., 2009; Seal et al., 2007; Goldberg, Eisen, True, \& Henderson, 1990). In a large-scale prospective study of 48,481 combat exposed veterans, Jacobson and colleagues (2008) found that National Guard/Reserve and younger aged 
servicemembers were at a greater risk for alcohol misuse - described as alcohol-related problems, new onset of heavy weekly drinking, and binge drinking (Jacobson et al., 2008). Likewise, researchers observed a two-fold increase in post-deployment alcohol-related behavioral problems in a retrospective study involving 1,080 U.S. soldiers returning from Iraq (Wilk et al., 2010). Moreover, in a representative, longitudinal study of 88,235 Operation Iraqi Freedom (OIF) veterans, Milliken and colleagues (2007) found that $12 \%$ of active duty and $15 \%$ of National Guard/Reserve troops reported alcohol-related consequences 3 to 6 months post-deployment (Milliken et al., 2007). As these studies demonstrate, exposure to combat may result in an increased risk in alcohol misuse.

There is considerable evidence for the link between PTSD and alcohol misuse among military veterans (King, King, Fairbank, Keane, \& Adams, 1998; Jakupcak et al., 2010; Shipherd, Stafford \& Tanner, 2005). Research indicates that Iraq and Afghanistan veterans with PTSD have alcohol abuse rates that are twice as high as those found among nonmilitary young males (Institute of Medicine, 2013). Additionally, a recent report which examined several factors related to post-deployment alcohol misuse in a sample of National Guardsmen $(\mathrm{n}=348)$ cited combat related PTSD as a significant factor in the onset of alcohol use disorders (Kelhe et al., 2012). PTSD is a psychiatric condition characterized by reexperiencing (e.g., acting or feeling as if the traumatic event were recurring), avoidant and/or numbing (e.g., feelings of detachment or estrangement from others), and hyperarousal symptoms (e.g., irritability or outbursts of anger; APA, 2000). Hypothesized explanations for the relationship between PTSD and alcohol misuse vary widely and include the use of alcohol to reduce symptom distress (e.g., self-medication; Khantzian, 1985), which subsequently, is reinforced through symptom alleviation (Jacobsen et al., 2001). Another theory points to a genetic and environmental vulnerability that increases the likelihood of developing both PTSD and alcohol use problems following a traumatic event (McLeod et al., 2001; Scherrer et al., 2008; Xian et al., 2000). Moreover, evidence has cited alcohol's role in the increase of endorphin levels as a possible reason for the co-morbidity between PTSD and alcohol misuse (Volpicelli et al., 1999).

Socio-demographic factors such as younger age (Ferrier-Auerbach et al., 2009; Stahre, et al., 2009; Bray et al., 2003), White race (Nolen-Hoeksema, 2004; Naimi et al., 2003), male gender (Nolen-Hoeksema, 2004; Naimi et al., 2003), single marital status (Ferrier-Auerbach et al., 2009; Fertig \& Allen, 1996), and lower levels of educational attainment (Ames \& Cunradi, 2004; Bray et al., 2003) are well documented risk factors for alcohol misuse among military servicemembers. A cross-sectional study of 514 National Guardmembers found that younger age predicted higher quantity of drinking prior to deployment (Ferrier-Auerbach et al., 2009). In the same study, single marital status was found to predict greater total drinking and higher frequency of heavy drinking (Ferrier-Auerbach et al., 2009). Together, these results suggest that certain socio-demographic variables contribute to an increased risk for high risk alcohol drinking.

\section{Resilience}

A recent report has suggested that a key factor playing a protective role against alcohol misuse among U.S. military combat troops is resilience (Green et al., 2010). Resilience is universally described as an individual's ability to thrive despite adversity (Connor \& Davidson, 2003; Luthar, Cicchetti, \& Becker, 2000; Rutter, 1987; Masten, 1994, p.3). Additionally, resilience has been thought of as a dynamic, multidimensional construct (Luthar, Cicchetti, \& Becker, 2000; Zimmerman \& Arunkumar, 1994), largely comprised of protective processes (biological, cognitive, and spiritual), which aids in finding positive meaning in stressful situations (Richardson, 2002). While early scholars posited resilience as a biological (Rutter, 2008) or behavioral trait (Wagnild \& Young, 1993; Masten, 1994), modern theories generally consider resilience as a state of functionality consisting of 
personal characteristics and protective factors that foster adaptation to stress (Luthar, Cicchetti, \& Becker, 2000; Zautra, Hall, \& Murray, 2010).

Validation studies of resilience (as measured by the Connor Davidson Resilience Scale (CDRISC) in diverse samples have provided preliminary support for the inverse relationship between resilience and psychological trauma (Campbell-Sills \& Stein, 2007; Wang, Shi, Zhang, \& Zhang, 2010; Burns \& Antsey, 2010; Notario-Pacheco et al., 2011). Furthermore, the relation between resilience and adverse physical and mental health outcomes has been documented among various samples including community (Connor, Davidson, \& Lee, 2003), elderly (Wagnild \& Young, 2007), and military populations (Youssef et al., 2013; Youssef et al., 2013; Green et al, 2010). The core characteristic of resilience (as measured by the 10-item version of the CD-RISC) encompasses the strengthening effect of stress, positive acceptance of and successful adaptation to change, and self-efficacy (Connor \& Davidson, 2003; Campbell-Sills \& Stein, 2007). Resilience characteristics have been shown to provide protection against alcohol misuse (Lerner \& Vicary, 1984) as well as aid in the recovery from substance misuse (Benda et al., 2002). Additionally, improvement in resilience over time among individuals with PTSD has been documented in a pharmaceutical trial of venlafaxine (Davidson et al., 2008), providing initial evidence that resilience can be bolstered in trauma exposed populations.

Studies examining the longitudinal effects of resilience on alcohol misuse in Iraq and Afghanistan era samples are lacking. Given the magnitude of alcohol misuse in the military and the serious financial, psychological, and physical consequences associated with its use (Rhem, 2000), research on the mechanisms that may buffer against alcohol misuse is vital. Further evaluation of resilience in alcohol misuse populations could assist in understanding risk and protective factors associated with substance abuse.

In a previous retrospective study of U.S. Iraq and Afghanistan combat exposed veterans $(n=497)$, we found that higher levels of resilience were related to lower problem alcohol drinking rates. This relationship remained even after adjusting for the influence of combatrelated PTSD (Green et al., 2010). Data have also shown that resilience is inversely related to substance misuse and is protective overtime (Smith et al., 1995). Following the results of the aforementioned studies, the present study sought to investigate the longitudinal effects of a theorized protective factor, resilience, against alcohol misuse adjusting for sociodemographic factors, trauma-related variables, and self-reported history of alcohol abuse. We hypothesized that: (1) lower baseline resilience will be related to higher levels of alcohol misuse at one-year follow-up; (2) demographic variables, particularly younger age, White race, male gender, single marital status, and lower educational attainment will be associated with higher severity of alcohol misuse; (3) change in baseline resilience will be negatively related to severity of alcohol misuse; and (4) Combat exposure, probable PTSD, and demographic variables (younger age, White race, single marital status, lower educational attainment) will be related to alcohol misuse at one-year follow-up in persons who deployed to Iraq and Afghanistan.

\section{Methodology}

\section{Participants and Procedures}

The sample was drawn from the National Post-Deployment Adjustment Study (NPDAS) survey - a prospective study of mental and physical health symptoms in U.S. military veterans who served on or after September 11, 2001 and were separated from active duty or served in the National Guard or Reserves (Elbogen et al., 2013). A randomized list of prospective subjects $(\mathrm{n}=3000)$ was provided by the U.S. Department of Veterans Affairs Environmental Epidemiological Service (EES). Established selection parameters for the 
study sample included an oversampling for women and stratification by gender. The study sample appeared representative of separated veterans with respect to geography (representation of 50 states, Washington D.C. and 4 territories), race/ethnicity (72.65\% White and $27.35 \%$ Black or African American, Hispanic or other) and military service branch (Center for Health Promotion and Prevention Medicine, 2010). Data collection took place between August 2009 and December 2011.

Institutional Review Board (IRB) approval for the research study was obtained at the Department of Veterans Affairs Medical Center in Durham, North Carolina and the University of North Carolina, Chapel Hill, North Carolina. Informed consent involved an acknowledgement of study procedures. Study participants were recruited at baseline and one-year follow-up through the use of Dillman's Tailored Design Method (TDM; Dillman, 2007; Dillman, 1978). The Dillman approach to survey sampling is generally considered the standard for telephone or mailed surveys and involves a systematic tailoring of interval mailings thereby encouraging high response rates (Dillman, 1978).

At the start of the study, prospective subjects were mailed a personalized, introductory letter describing the purpose of the study and details of an upcoming web-based survey opportunity. After four days, an invitation letter containing the survey instructions, a commemorative postage stamp booklet (valued at $\$ 4.40$ ), and a password for completing the web-based survey was mailed. Non-responders were followed up sixteen days after the invitation mail-out with a reminder postcard and were subsequently mailed a paper version of the web-based survey with a pre-paid postage return envelope. A final letter of invitation was sent approximately two months later to encourage participation and provide information relating to the end of the survey the following week.

Surveys were mailed to 3,000 potential subjects. Five hundred and one $(\mathrm{n}=501)$ were excluded from the study sample due to incomplete addresses/death $(n=63)$ and erroneous addresses $(\mathrm{n}=438)$. An additional subset of potential subjects considered as non-responders $(n=1111)$ were removed resulting in a final baseline sample of $n=1388$. The cumulative participant response rate was $56 \%$, a comparably high percentage when compared to recent national surveys conducted in similar military samples (Riddle et al., 2008; Beckham et al., 2008). The follow-up $(n=1090)$ study sample exhibited a retention rate of $79 \%$ from baseline to one-year follow-up.

\section{Study Measures}

Demographic Information-Demographic data collected as part of this study included age, gender, race, marital status (unmarried, married, married- but separated), education level (junior high school, middle school, partial high school, high school graduate (G.E.D.), partial college, associate's degree, bachelor's degree, graduate degree), working status (fulltime, part-time, retired, unemployed, full-time student, part-time student, stay-at-home caretaker, on disability, or have filed for disability, other), military service status (on active duty, in the ready reserves, in the individualized ready reserve, in the national guard, in the inactive national guard, discharge from the military), and deployment history (number of deployments to either Afghanistan or Iraq).

Resilience-The Connor-Davidson Resilience Scale (CD-RISC-10) is a brief, validated instrument for evaluating resilience (Campbell-Sills \& Stein, 2007). Preliminary evidence has shown the CD-RISC-10 to be a more psychometrically sound measure of resiliency in Iraq and Afghanistan Era military populations when compared to the 25 -item version. The CD-RISC-10 consists of items $1,4,6,7,8,11,14,16,17$, and 19 from the full measure with each item rated on a 5-point Likert scale ( 0 "not true at all" to 4 "true nearly all of the time"). Items comprised in the CD-RISC-10 are considered to be reflective of both 
adaptability and commitment (e.g., "I can deal with whatever comes my way", "I am not easily discouraged by failure."). The total score ranges from (0-40), with higher scores indicating a greater degree of resiliency. Additionally, the CD-RISC-10 has demonstrated excellent psychometric properties among differing samples including college students, trauma-exposed adult women, and non-Western populations (Gucciardi, Jackson, Coulter, \& Mallett, 2011; Wang, Shi, Zhang, \& Zhang, 2010; Scali et al., 2012; Campbell-Sills \& Stein, 2007). The estimates of reliability for the CD-RISC-10 were sufficient in both the initial validation study (Cronbach $\alpha=.89$; Campbell-Sills \& Stein, 2007) and current sample (Cronbach $a=0.93$ ). A change in resilience from baseline to one-year follow-up could denote an increase in resilience (positive value) or a decrease in resilience (negative value).

Combat Exposure-Combat exposure was measured using the Combat Experiences Scale (CES) from the Deployment Risk and Resilience Inventory (DRRI; King et al., 2003). Comprised of 15 items in total, the CES assesses exposure to combat or war related situations, such as firing a weapon, being fired on or receiving friendly fire, and witnessing an attack, injury, or death (King et al., 2003; Vogt et al., 2008). Response items are rated on a 6 -point Likert type scale ( $1=$ Never; $6=$ Daily or almost daily), with higher scores representing greater levels of combat exposure. The CES has demonstrated good reliability when tested in an Operation Iraqi Freedom (OIF) veteran population (Vogt et al., 2008).

Probable Posttraumatic Stress Disorder (PTSD)—PTSD severity was assessed with the Davidson Trauma Scale (DTS), a brief global assessment scale for posttraumatic stress disorder (PTSD; Davidson et al., 1997). The DTS includes 17 items that correspond to each of the 17 DSM-IV symptoms of PTSD. Respondents rate each of the 17 items on both frequency and severity. A cut-off value of 48 or more on the DTS is believed to reflect the presence of PTSD. Additionally, the DTS has demonstrated reliability and validity in OEF/ OIF veterans as evident by sensitivity of 0.82 , a specificity of 0.94 , and a diagnostic efficiency of .87 using the Structured Clinical Interview for DSM-IV-TR Axis I disorders (McDonald, Beckham, Morey, \& Calhoun, 2009).

Alcohol Misuse-To measure current level of alcohol use, we employed the Alcohol Use Disorders Identification Test (AUDIT) (Saunders, Aasland, Babor, de la Puente, \& Grant, 1993), which is a 10-item self-report instrument used for assessing alcohol misuse.

Responses range from 0 to 40 . A total score of 8 or more in men (or 7 or more in women) indicates a strong likelihood of hazardous and harmful alcohol use, as well as possible alcohol dependence (Babor et al., 2001). The AUDIT demonstrated adequate internal consistency when tested in a similar military cohort $(\alpha=.85)$ and was estimated at $\alpha=.85$ in the present sample (Crawford et al., in press).

Moreover, history of alcohol abuse was assessed during the baseline survey. Participants were asked to indicate whether the statement, "I abused alcohol" was applicable before, during, between, and/or after their military deployment.

\section{Statistical Analyses}

Women constituted 33\% of the current sample but represent an estimated $15.6 \%$ of the military, based on September 2009 Defense Manpower Data Center figures (Center for Health Promotion and Prevention Medicine, 2010); data in the current study were weighted to reflect the latter proportion, which adjusted the total sample to a weight-adjusted followup sample of $n=866$.

Descriptive statistics for the demographics and clinical characteristics, outcome variables, and potential predictors were calculated including the mean, standard deviations, counts, and 
frequencies for continuous and categorical variables respectively. Bivariate correlations between independent variables and alcohol misuse (AUDIT total score) at follow-up were computed using Pearson product-moment and point-biserial correlation coefficient procedures.

Multiple linear regression analyses were utilized to examine predictors of alcohol misuse (AUDIT total score) at one-year follow-up. Socio-demographic and trauma-related variables such as age (Ferrier-Auerbach et al., 2009; Stahre, et al., 2009; Bray et al., 2003), gender (Nolen-Hoeksema, 2004; Naimi et al., 2003), White race (Nolen-Hoeksema, 2004; Naimi et al., 2003), being married (Ferrier-Auerbach et al., 2009; Fertig \& Allen, 1996), postsecondary education, combat exposure (Hoge, Auchterlonie, \& Milliken, 2006; Bray \& Hourani, 2007; Schlenger et al., 2007; Kulka et al., 1990b; Marx et al., 2009; Seal et al., 2007; Goldberg, Eisen, True, \& Henderson, 1990), and PTSD (using a total DTS cut-off score of $\geq 48$; King, King, Fairbank, Keane, \& Adams, 1998; Jakupcak et al., 2010; Shipherd, Stafford \& Tanner, 2005) were considered for analyses due to the literature evidence. Additionally, all statistical models controlled for self-reported history of alcohol abuse. Presence of multicolinearity among predictor variables in the regression models was assessed using a variance inflation factor. Adjusted $R^{2}$ values and probability values were also calculated. Statistical significance was determined at $p<.05$. A separate multiple linear regression analysis was also conducted to evaluate whether the change in resilience from baseline to the one-year follow-up predicted alcohol misuse (AUDIT total score) at followup.

Finally, a multiple logistic regression analysis was conducted to evaluate the association between baseline resilience and alcohol misuse (measured dichotomously using an AUDIT cutoff score of $\geq 7$ and $\geq 8$ for women and men respectively) at one-year follow-up, after adjusting for a range of important socio-demographic factors (e.g. age, gender, race, level of education attainment, marital status), trauma-related variables (combat exposure, probable PTSD) and self-reported history of alcohol misuse. All statistical analyses were performed using SAS, version 9.1 (SAS Institute, Cary, N.C.).

\section{Results}

\section{Sample Characteristics}

Participants reported a mean age of 37 years $(S D=9.57)$, and $84 \%$ were male. The study group was comprised primarily of Whites (78\%), with other racial groups representing $22 \%$ of the remaining sample (13\% Black and the remaining 3\% Asian, $0.92 \%$ Native American/ Alaskan Native, $0.74 \%$ Native Hawaiian or Other Pacific Islander, 3\% more than one race, and $1.5 \%$ other). Sixty-four percent of participants were married, $81 \%$ were employed, and $82 \%$ reported having education beyond high school. Fifty-two percent of participants endorsed serving in the reserve component of the Armed Forces (i.e., National Guard and/or Reserves) and the remainder were active duty. The majority of the sample (82\%) had been deployed to Iraq or Afghanistan and the remaining (18\%) served during the era (military service during the time period) but not in theater (i.e., military service outside of the officially designated combat zone areas in Iraq and/or Afghanistan). Nearly half (48\%) of the sample endorsed combat exposure based on the CES.

\section{Prevalence of Alcohol Misuse, Probable PTSD, and Resilience}

The mean AUDIT score at baseline and the one-year follow-up for the study sample was $5.54(S D=6.63)$ and $5.27(S D=4.98)$ respectively. The percent of females with an AUDIT score $\geq 7$ was $17 \%$ and the percent of males with a score $\geq 8$ was $26 \%$. Based on a single survey item (not as part of the AUDIT), 23\% reported alcohol abuse prior to the baseline 
interview. Rates of probable PTSD (as defined by a DTS cut-off score of 48) were estimated at $18 \%$. The mean score for the CD-RISC was $30.5(S D=6.63)$. The mean change in resilience for the sample was 0.33 ( $\mathrm{SD}=5.38$ ), suggesting very little change for the overall sample in resilience. However, examination with in participants did show change in resilience, with a range from -32 to 40 , reflecting that resilience decreased for some participants (39\%), remained the same (12\%) and improved for others (49\%).

\section{Bivariate Correlations}

Pearson product-moment and point-biserial correlations were used to assess the relationship between independent variables and alcohol misuse (AUDIT total score) at one-year followup. Age $(r(1074)=-.20, p<.0001)$, gender $\left(r_{p b}(1074)=.11, p<.001\right)$, marital status $\left(r_{p b}(1074)=-.12, p<.0001\right)$, post-secondary education $\left(r_{p b}(1074)=.13, p<.0001.\right)$, selfreported history of alcohol misuse $\left(r_{p b}(1074)=.41, p<.0001\right)$, probable $\operatorname{PTSD}\left(r_{p b}(1074)=\right.$. $18, p<.0001)$, combat exposure $\left(r_{p b}(1074)=.17, p<.0001\right)$, and baseline resilience $(r(1059)=-.24, p<.0001)$ were consistently related in the expected direction to alcohol misuse at one-year follow-up. Race $(r(1071)=.04, p=.18)$ failed to be related to alcohol misuse at one-year follow-up.

\section{Association of Baseline Resilience, Change in Resilience, Sociodemographic Factors, Trauma Variables, and Alcohol Misuse}

Three separate regression analyses were conducted for evaluating alcohol misuse (AUDIT total score) at one-year follow-up. Covariates for the statistical models included age, gender, race, being married, post-secondary education, probable PTSD, combat exposure, and selfreported history of alcohol abuse. In the first statistical model, baseline resilience was utilized as the predictor variable. In the second statistical model, change in resilience from baseline to one-year follow-up served as the predictor variable. In the third statistical model, the dependent variable (alcohol misuse at one-year follow-up) was dichotomized (alcohol misuse or not). Results for Models 1 and 2 are summarized in Table 1 and results for Model 3 are displayed in Table 2.

In Model 1, as predicted, lower baseline resilience, was associated with alcohol misuse at follow-up even after accounting for the presence of combat exposure, PTSD symptom severity, and a self-reported history of alcohol abuse. Younger age and male gender were associated with higher alcohol use. The overall model was statistically significant, and accounted for $21 \%$ of the variability in alcohol misuse at follow-up.

In Model 2, the same covariates as in Model 1 were related in the expected direction. In addition, change in resilience was also related to alcohol misuse at one-year follow-up. The overall model was significant and accounted for $23 \%$ of the variability in alcohol misuse at follow-up.

In Model 3, a logistic regression was conducted to examine the relationship between baseline resilience and alcohol misuse (defined by an AUDIT score of $\geq 8$ in men or $\geq 7$ for women) at one-year follow-up. Table 2 provides a summary of the analysis results. Main effects were noted for age, combat exposure, self-reported history of alcohol abuse, and baseline resilience.

\section{Discussion}

To our knowledge this is the first study to examine the longitudinal effects of psychological resilience on alcohol misuse in a nationally representative U.S. military sample. As hypothesized, lower resilience at baseline was predictive of alcohol misuse at one-year 
follow-up, even after accounting for trauma related variables (e.g., combat exposure, probable PTSD) and self-reported history of alcohol abuse. The present study extends previous knowledge related to the resilience and substance use literature in military samples by demonstrating the protective nature of resilience against alcohol misuse over time in an Iraq and Afghanistan era sample (Green et al., 2010; Bartone et al., 2012; King et. al., 1998).

The association between younger age and alcohol misuse has been repeatedly shown in empirical studies of alcohol misuse (Mattiko et al., 2011; Naimi et al., 2003; Filmore et al., 1991; Richards, Goldberg, Rodin \& Anderson, 1989). This relationship was observed in the current study as well as in studies involving other military cohorts (Jakupcak et al., 2010; Bray et al., 2004; Ames \& Cunradi, 2004). Consistent with the literature on risks for alcohol misuse, male gender and White race was associated with alcohol misuse (Nolen-Hoeksema, 2004; Naimi et al., 2003). While numerous studies have reported an association between combat exposure and alcohol misuse (Hoge, Auchterlonie, \& Milliken, 2006; Bray \& Hourani, 2007; Schlenger et al., 2007; Kulka et al., 1990; Marx et al., 2009; Seal et al., 2007; Goldberg, Eisen, True, \& Henderson, 1990), this relationship was only supported in the logistic regression model. Hence, future studies should explore this relationship in greater detail to extrapolate the contribution of combat exposure in alcohol misuse taking into account prior history of alcohol abuse.

Another important finding from this study was an inverse relationship between change in resilience and severity of alcohol misuse. This finding highlights the view of resilience as a dynamic process, which varies over time (Flach, 1980; Rutter, 1985; Flach, 1988; Luthar, 2000). Interestingly, the addition of change of resilience to the regression analyses increased the explanatory power of the overall statistical model $\left(\mathrm{R}^{2}\right.$ value of .21 to .23$)$.

The significant relationship found between level of education attainment and alcohol misuse at one-year follow-up in the regression model for deployed veterans can be partly explained by characteristics of the study sample. A little over half of respondents who reported being deployed to Iraq and Afghanistan were comprised of junior enlisted personnel (51\%, E1E5). Generally, individuals at these service rank levels are less likely to have attained a college degree because they often enlist in the military before pursuing higher education (Ames \& Cunradi, 2004; Watkins \& Sherk, 2008).

This is the first longitudinal investigation of resilience and alcohol misuse in an U.S. Iraq and Afghanistan era military sample. Given that several hardiness themed concepts are encompassed in the CD-RISC, an understanding of the protective effect of resilience over time can be drawn from the hardiness literature. As described by Bartone and colleagues (2012), hardiness is a "resilience resource" comprised of a triad of personality traits (commitment, control, and challenge) which function to facilitate both survival and life enhancement through the positive appraisal of stressful situations (Kobasa et al., 1981; Kobasa, 1979). Studies of hardiness in military populations have demonstrated its importance for resilience outcomes. For example, findings from the National Vietnam Veterans' Readjustment Study (NVVRS) found that hardiness was important in maintaining resilience and recovery processes after the Vietnam War (King, King, Fairbank, Keane, \& Adams, 1998). Along similar lines, Bartone and colleagues (2012) observed an increased risk for alcohol abuse among individuals with low levels of hardiness and high levels of avoidance coping in a Norwegian military combat sample ( $\mathrm{n}=1402$; Bartone et al., 2012). Unlike the present study, researchers did not take into account the contribution of prior alcohol misuse, a documented predictor of future misuse. Although these studies examined a resilience related concept (e.g., hardiness), findings highlight the protective contributions of resilience processes overtime against negative function. 
Although the statistical models for alcohol misuse were significant in this study, it is clear that there are additional variables important for alcohol misuse; for example, genetic factors, family history, age at onset of drinking, and childhood maltreatment (Marcos et al., 2011; Ducci \& Goldman, 2008; Young, Hansen, Gibson \& Ryan, 2006; Hingson, Heeren, \& Winter, 2006; McCarty et al., 2004; Hingson et al., 2003; Carbbe, 2002; Kendler, 2001; DeWit, Adlaf, Offord, \& Ogborne, 2000; Long et al., 1998; Beirut et al., 1998; Clapper et al., 1995). Future research should examine the interrelationships between these factors and alcohol misuse to further clarify the protective role resilience plays, in civilian and veteran populations alike.

Limitations of the current study include the use of self-report instruments. Evidence has shown that self-report data are often susceptible to social desirability and response bias (Mensch \& Kandel, 1988). Another limitation concerns the use of one measure of resilience. While the 10-item CDRISC is a reliable measure of resilience, other constructs (e.g. social support, religiosity) important for protection against alcohol misuse are not assessed in this abbreviated version. For example, multiple studies have demonstrated that religious beliefs/ involvement buffer the uptake of alcohol by non-drinkers as well as heavy use in current drinkers (Miller, 2002; Amey, Albrecht, \& Miller, 1996; Heath \& Martin, 1988; Heath et al., 1999; Maes et al., 1999; Midanik \& Clark, 1994). The use of a single item for self-reported history of alcohol abuse and a lack of an operational definition of alcohol abuse provided to participants can also be cited as a limitation. Consideration of these factors in future studies will increase the predictability of alcohol misuse in this population.

In conclusion, results of the present study demonstrated a protective effect of resilience against alcohol misuse overtime in a U.S. Iraq/Afghanistan era military sample. Alcohol misuse is a preventable public health problem. Its consequences in the military may adversely affect areas related to organizational readiness and physical or psychological fitness (Jolee, 2007). Given alcohol's reported involvement in the surge of suicidal deaths in returning troops (LeardMann et al., 2013; Chiarelli, 2010), it is vital that efforts are placed on identifying reliable mechanisms and programs that bolster protection against high risk drinking. One such effort designed to enhance the resilience capacity in troops is the U.S. Army's Master Resilience Training Course (MRTC) - a curriculum of the Comprehensive Soldier Fitness program designed solely for teaching resilience-based skills (Lester, Harms, Herian, Krasikova, \& Beal, 2011). While the MRTC has received considerable criticism for its lack of scientific support, initial findings have reported positive effects (Lester et al., 2011). Additionally, resilience based interventions within positive psychology are currently being tested for their capacity to reduce the occurrence of alcohol misuse (Seligman \& Csikszentmihalyi, 2000). While it is encouraging that the military has implemented several initiatives aimed at bolstering resilience and reducing the prevalence of alcohol misuse among troops, further research is needed to determine the effectiveness of these interventions over time (Foran, 2012; Fava \& Tomba, 2009).

Moreover, the results of this study suggest that it would be beneficial for clinicians to evaluate resilience (as measured by the CD-RISC) as part of alcohol misuse assessment (Campbell-Sills \& Stein, 2007; Connor \& Davison, 2003) as such assessment could provide relevant information for treatment planning. It may also be useful to include resilience enhancement treatment components (as they are empirically identified) in treating alcohol misuse. Although there has yet to be an identified efficacious resilience enhancement treatment, components of cognitive behavioral approaches such as coping strategies and mindfulness (Segal, Williams, \& Teasdale, 2002) may serve to enhance resilience (Davidson et al., 2005); however, this remains an empirical question. The evaluation of protective, as well as risk factors in alcohol misuse may contribute to a more comprehensive assessment and treatment of alcohol misuse. 


\title{
Acknowledgments
}

\author{
Role of Funding Sources
}

This work was supported by a National Institute of Mental Health (NIMH) Grant\# R01MH080988, National Institute on Drug Abuse (NIDA) Grant\# K24DA016388, and Research Supplement to Promote Diversity in Health Related Research [supplement to NIMH Grant\# R01MH062482-05A2S1]. The NIMH had no further role in study design; in the collection, analysis and interpretation of data; in the writing of the report; and in the decision to submit the paper for publication.

We would like to extend our appreciation to the military servicemembers and veterans for their participation and the research study staff members for their diligent work and essential contributions to the management of this study. In particular, we would like to acknowledge Annie Stanley for her contributions of content knowledge related to alcohol misuse. The views expressed in this article are those of the authors and do not necessarily represent the views of the Department of Veterans Affairs or any of the institutions to which the authors are affiliated.

\section{References}

American Psychiatric Association. Diagnostic and statistical manual of mental disorders. 4. Washington, DC: 2000. Revised

Ames GM, Cunradi C. Alcohol use and preventing alcohol-related problems among young adults in the military. Alcohol Research and Health. 2004; 28(4):252-257.

Amey CH, Albrecht SL, Miller MK. Racial differences in adolescent drug use: The impact of religion. Substance Use Misuse. 1996; 31:1311-1332. [PubMed: 8879076]

Babor, T.; Campbell, R.; Room, R.; Saunders, J., editors. Lexicon of Alcohol and Drug Terms. Geneva, Switzerland: World Health Organization; 1994.

Babor, TF.; Higgins-Biddle, J.; Saunders, JB.; Monteiro, MG. AUDIT - The Alcohol Use Disorders Identification Test: Guidelines for Use in Primary Care. 2. Geneva, Switzerland: World Health Organization; 2001.

Babor TF, Kranzler HR, Lauerman RJ. Early detection of harmful alcohol consumption: comparison of clinical, laboratory, and self-report screening procedures. Addictive Behaviors. 1989b; 14:139-157. [PubMed: 2728952]

Bartone PT, Hystad SW, Eid J, Brevik JI. Psychological Hardiness and coping style as risk/resilience factors for alcohol abuse. Military Medicine. 2012; 177(5):517-24. [PubMed: 22645877]

Beckham JC, Becker ME, Hamlett-Berry KW, Drury PD, Kang HK, Wiley MT, Calhoun PS, Moore SD, Bright MA, McFall ME. Preliminary findings from a clinical demonstration project for veterans returning from Iraq or Afghanistan. Military Medicine. 2008; 173(5):448-51. [PubMed: 18543565]

Benda BB, Belcher JR. Alcohol and other drug problems among homeslss veterans: A life-course theory of forgiveness. Alcoholism Treatment Quarterly. 2006; 24(1/2):147-170.10.1300/ J020v24n01_09

Bierut LJ, Dinwiddie SH, Begleiter H, Crowe RR, Hesselbrock V, Nurnberger JI, Porjesz B, Schuckit MA, Reich T. Familial transmission of substance dependence: alcohol, marijuana, cocaine, and habitual smoking. Archives of General Psychiatry. 1998; 55:982-988. [PubMed: 9819066]

Bohn MJ, Babor TF, Kranzler HR. The Alcohol Use Disorders Identification Test (AUDIT): validation of a screening instrument for use in medical settings. Journal of Studies on Alcohol. 1995; 56(4): 423-432. [PubMed: 7674678]

Bray RM, Hourani LL. Substance use trends among active duty military personnel: findings from the United States Department of Defense Health Related Behavior Surveys, 1980-2005. Addiction. 2007; 102(7):1092-101. [PubMed: 17567397]

Bray, RM.; Hourani, L.; Rae, KL.; Dever, JA.; Brown, JM.; Vincus, AA.; Pemberton, MR.; Marsden, ME.; Faulkner, DL., et al. 2002 Department of Defense Survey of Health Related Behaviors Among Military Personnel. Research Triangle Park, NC: RTI International; 2004.

Bray, RM.; Hourani, LL.; Rae, KL., et al. 2002 Department of Defense Survey of Health-Related Behaviors Among Military Personnel. Research Triangle Park, NC: RTI International; 2003. 
Burns RA, Anstey KJ. The Connor-Davidson Resilience Scale (CD-RISC): Testing the invariance of a uni-dimensional measure that is independent of positive and negative affect. Personality and Individual Differences. 2010; 48:527-533. 10.1016/ j.paid.2009.11.026.

Calhoun PS, Elter JR, Jones ER, Kudler H, Straits-Troster K. Hazardous alcohol use and receipt of risk-reduction counseling among U.S. veterans of the wars in Iraq and Afghanistan. The Journal Of Clinical Psychiatry. 2008; 69(11):1686-1693. [PubMed: 19012816]

Campbell-Sills L, Stein MB. Psychometric analysis and refinement of the Connor-davidson Resilience Scale (CD-RISC): Validation of a 10-item measure of resilience. Journal of Traumatic Stress. 2007; 20(6):1019-28.10.1002/jts.20271 [PubMed: 18157881]

Center for Health Promotion and Prevention Medicine. Epidemiological Report No. 14HK-0BW9-10c. 2010. Analyses of Army suicides, 2003-2009; p. 17

Chiarelli, PW. Army health promotion risk reduction suicide prevention report 2010. 2010. Retrieved on March 20, 2013 from http://www.army1.army.mil/hr/suicide/docs/Commanders\%20Tool \%20Kit/HPRRSP_Report_2010_v00.pdf

Clapper RL, Buka SL, Goldfield EC, Lipsitt LP, Tsuang MT. Adolescent problem behaviors as predictors of adult alcohol diagnoses. International Journal of Addiction. 1995; 30:507-523.

Connor KM, Davidson JR. Development of a new resilience scale: the Connor-Davidson Resilience Scale (CD-RISC). Depression and Anxiety. 2003; 18(2):76-82. [PubMed: 12964174]

Connor KM, Davidson JR, Lee LC. Spirituality, resilience, and anger in survivors of violent trauma: a community survey. Journal of Traumatic Stress. 2003; 16(5):487-494. [PubMed: 14584633]

Connor KM, Sutherland SM, Tupler LA, Malik ML, Davidson JRT. Fluoxetine in post-traumatic stress disorder: randomized, double-blind study. British Journal of Psychiatry. 1999; 175:17-22. [PubMed: 10621763]

Crabbe JC. Alcohol and genetics: New models. American Journal of Medical Genetics. 2002; 1114(8): 969-974.10.1002/ajmg.b.10984 [PubMed: 12457395]

Crawford EF, Fulton JJ, Swinkels CM, Beckham JC, et al. Diagnostic efficiency of the AUDIT-C in U.S. veterans with military service since. Drug and Alcohol Dependence. Sep 11.2001 in press. 10.1016/j.drugalcdep.2013.01.012

Davidson JRT, Book SW, Colket JT, Tupler LA, Roth S, David D, Hertzberg M, Mellman T, Beckham JC, Smith R, Davison RM, Katz R, Feldman M. Assessment of a new self-rating scale for post-traumatic stress disorder. Psychological Medicine. 1997; 27:153-160.10.1017/ S0033291796004229 [PubMed: 9122295]

Davidson JRT, Payne VM, Connor KM, Foa EB, Rothbaum BO, Hertzber MA, Weisler RH. Trauma, resilience and saliostasis: effects of treatment in post-traumatic stress disorder. International Clinical Psychopharmacology. 2005; 20(10):43-48. [PubMed: 15602116]

Dillman, DA. Mail and telephone surveys: The total design method. New York, NY: Wiley; 1978.

Dillman, DA. Mail and internet surveys: The tailored design method. 2. New York, NY: Wiley; 2007.

Ducci F, Goldman D. Genetic approaches to addiction: genes and alcohol. Addiction. 2008; 103(9): 1414-28.10.1111/j.1360-0443.2008.02203.x [PubMed: 18422824]

DeWit DJ, Adlaf EM, Offord DR, Ogborne AC. Age at first alcohol use: a risk factor for the development of alcohol disorders. American Journal of Psychiatry. 2000; 157:745-750.10.1176/ appi.ajp.157.5.745 [PubMed: 10784467]

Eisen SV, Schultz MR, Vigt D, Glickman ME, Elwy AR, Drainoni ML, Osei-Bonsu PE, Martin J. Mental and physical health status and alcohol and drug use following return from deployment to Iraq or Afghanistan. American Journal of Public Health. 2012; 102(S1):S66-S73.10.2105/AJPH. 2011.300609 [PubMed: 22390605]

Elbogen EB, Johnson SJ, Wagner HR, Kinneer P, Kang H, Timko C, Vasterling JJ, Beckham JC. A Fresh Look at Treatment Utilization in Iraq and Afghanistan Era Veterans: Findings from the National Post-Deployment Adjustment Study. Psychiatric Services. in press.

Fava GA, Tomba E. Increasing psychological well-being and resilience by psychotherapeutic methods. Journal of Personality. 2009; 77(6):1903-1934. [PubMed: 19807860]

Ferrier-Auerbach AG, Kehle SM, Erbes CR, Arbisi PA, Thuras P, Polusny MA. Predictors of alcohol use prior to deployment in National Guard Soldiers. Addictive Behaviors. 2009; 34:625-

631.10.1016/j.addbeh.2009.03.027 [PubMed: 19375239] 
Fertig JB, Allen JP. Health behavior correlates of hazardous drinking by army personnel. Military Medicine. 1996; 161:352-355. [PubMed: 8700332]

Fillmore KM, Hartka E, Johnstone BM, et al. A meta-analysis of life course variation in drinking. British Journal of Addiction. 1991; 86:1221-1267.10.1111/j.1360-0443.1991.tb01702.x [PubMed: 1836408]

Flach FF. Psychobiologic resilience, psychotherapy, and the creative process. Comprehensive Psychiatry. 1980; 21(6):510-519. [PubMed: 7428355]

Flach, FF. Resilience: Discovering a new strength at times of stress. Fawcett Columbine; New York: 1988.

Foran HM, Adler AB, McGurk D, Bliese PD. Soldiers' perceptions of resilience training and postdeployment adjustment: Validation of a measure of resilience training content and training process. Psychological Services. 201210.1037/a0028178

Gache P, Michaud P, Accietto C, Arfaoui S, Wenger O, Daeppen JB. The Alcohol Use Disorders Identification Test (AUDIT) as a screening tool for excessive drinking in primary care: reliability and validity of a French version. Alcoholism, Clinical, and Experimental Research. 2005; 29(11): 2001-2007.10.1097/01.alc.0000187034.58955.64

Goldberg J, Eisen SA, True WR, Henderson WG. A twin study of the effects of the Vietnam conflict on alcohol drinking patterns. American Journal of Public Health. 1990; 80(5):570-574. [PubMed: 2327534]

Green KT, Calhoun PS, Dennis MF, Beckham JC. Mid-Atlantic Illness Research, Education and Clinical Center Workgroup. Exploration of the Resilience Construct in Posttraumatic Stress Disorder Severity and Functional Correlates in Military Combat Veterans Who Have Served Since September 11 2001. Journal of Clinical Psychiatry. 2010; 71(7):823-830.10.4088/JCP. 09m05780blu [PubMed: 20584523]

Gucciardi D, Jackson B, Coulter T, Mallett C. Dimensionality and age-related measurement invariance with Australian cricketers. Journal of Sport and Exercise. 2011; 12:423-433.

Hawkins JD, Catalano RF, Miller JY. Risk and protective factors for alcohol and other drug problems in adolescence and early adulthood: Implications for substance abuse prevention. Psychological Bulletin. 1992; 112(1):64-105.10.1037/0033-2909.112.1.64 [PubMed: 1529040]

Heath AC, Madden PAF, Grant JD, McLaughlin TL, Todorov AA, Bucholz KK. Resiliency factors protecting against teenage alcohol use and smoking: Influences of religion, religious involvement and values, and ethnicity in the Missouri Adolescent Female Twin Study. Twin Research. 1999; 2(2):145-155.10.1375/twin.2.2.145 [PubMed: 10480749]

Heath AC, Martin NG. Teenage alcohol use in the Australian Twin Register: Genetic and social determinants of starting to drink. Alcoholism Clinical and Experimental Research. 1988; 12(6): 735-741.10.1111/j.1530-0277.1988.tb01337.x

Hoge CW, Auchterlonie JL, Milliken CS. Mental Health problems, use of mental health services, and attrition from military service after returning from deployment to Iraq and Afghanistan. JAMA. 2006; 295:1023-1032. [PubMed: 16507803]

Hingson RW, Heeren T, Jamanka A, Howland J. Age of drinking onset and unintentional injury involvement after drinking. JAMA. 2000; 284:1527-1533.10.1001/jama.284.12.1527 [PubMed: 11000646]

Hingson R, Heeren T, Zakocs R, Winter M, Wechsler H. Age of first intoxication, heavy drinking, driving after drinking, and risk of unintentional injury among US college students. Journal of Studies on Alcohol and Drugs. 2003; 64:23-31.

Hingson RW, Heeren T, Winter MR. Age of drinking onset and alcohol dependence. Archives of Pediatrics \& Adolescent Medicine. 2006; 160:739-746.10.1001/archpedi.160.7.739 [PubMed: 16818840]

Institute of Medicine. Substance use disorders in the US armed forces. Washington, DC: The National Academies Press; 2013.

Jacobson IG, Ryan MA, Hooper TI, Smith TC, Amoroso PJ, Boyko EJ, Gackstetter GD, Wells TS, Bell NS. Alcohol use and alcohol-related problems before and after military combat deployment. JAMA. 2008; 300:663-675. [PubMed: 18698065] 
Jacobsen LK, Southwick SM, Kosten TR. Substance use disorders in patients with posttraumatic stress disorder: A review of the literature. American Journal of Psychiatry. 2001; 158(8):1184-1190. [PubMed: 11481147]

Jakupcak M, Tull MT, McDermott MM, Kaysen D, Hunt S, Simpson T. PTSD symptom clusters in relationship to alcohol misuse among Iraq and Afghanistan war veterans seeking post-deployment VA health care. Addictive Behaviors. 2010; 35(9):840-843.10.1016/j.addbeh.2010.03.023 [PubMed: 20471180]

Jolee, D. Military readiness risks: A study of leader experiences with mandatory addiction referrals. 2007. Retrieved from ProQuest Digital Dissertations. (AAT 3250061)

Kehle SM, Ferrier-Auerbach AG, Meis LA, Arbisi PA, Erbes CR, Polusny MA. Predictors of postdeployment alcohol use disorders in National Guard soldiers deployed to Operation Iraqi Freedom. Psychology of Addictive Behaviors. 2012; 26(1):42-50.10.1037/a0024663 [PubMed: 21823766]

Kendler KS. Twin studies of psychiatric illness: An update. Archives of General Psychiatry. 2001; 58(11):1005-1014. 10-1001/pubs.Arch Gen Psychiatry-ISSN-0003-990x-58-11-ynv20356. [PubMed: 11695946]

Khantzian EJ. The self-medication hypothesis of addictive disorders: Focus on heroin and cocaine dependence. American Journal of Psychiatry. 1985; 142:1259-1264. [PubMed: 3904487]

King LA, King DW, Fairbank JA, Keane TM, Adams GA. Resilience-recovery factors in posttraumatic stress disorder among female and male Vietnam veterans: hardiness, postwar social support, and additional stressful life events. Journal of Personality and Social Psychology. 1998; 74(2):420-434. [PubMed: 9491585]

King, DW.; King, LA.; Vogt, DS. Manual for the Deployment Risk and Resilience Inventory (DRRI): A Collection of Scales for Studying Deployment-Related Experiences in Military Veterans. Boston, MA: National Center for PTSD; 2003.

Kobasa SC. Stressful life events, personality, and health Inquiry into hardiness. Journal of Personality and Social Psychology. 1979; 37 (1):1-11.10.1037/0022-3514.37.1.1 [PubMed: 458548]

Kulka, RA.; Schlenger, WE.; Fairbank, JA.; Hough, RL.; Jordan, BK.; Marmar, CR., et al. Trauma and the Vietnam War generation: Report of findings from the National Vietnam Veterans Readjustment Study. New York: Brunner/Mazel; 1990b.

Lambert VA, Lambert CE, Itano J, Inouye J, Kim S, Kuniviktikul W, Ito M. Cross-cultural comparison of workplace stressors, ways of coping and demographic characteristics as predictors of physical and mental health among hospital nurses in Japan, Thailand, South Korea and the USA (Hawaii). International Journal of Nursing Studies. 2004; 41(6):671-684. http://dx.doi.org/10.1016/ j.ijnurstu.2004.02.003. [PubMed: 15240091]

Lerner JV, Vicary JR. Difficult temperament and drug use: Analyses from the New York longitudinal study. Journal of Drug Education. 1984; 14:1-8. [PubMed: 6537440]

Lester, PB.; Harms, PD.; Herian, MN.; Krasikova, DV.; Beal, SJ. The Comprehensive Soldier Fitness Program Evaluation: Report \#3 Longitudinal Analysis of the Impact of the Master Resilience Training on Self-Reported Resilience and Psychological Health Data. 2011. Retrieved April 1, 2013 from http://www.ppc.sas.upenn.edu/csftechreport3mrt.pdf

Long JC, Knowler WC, Hanson RL, Robin RW, Urbanek M, Moore E, Bennett PH, Goldman D. Evidence for genetic linkage to alcohol dependence on chromosomes 4 and 11 from an autosomewide scan in an american indian population. American Journal of Medical Genetics. 1998; 81(3): 216-221.10.1002/(SICI)1096-8628(19980508)81:3<216::AID-AJMG2>3.0.CO;2-U [PubMed: 9603607]

Luthar SS, Cicchetti D, Becker B. The construct of resilience: a critical evaluation and guidelines for future work. Child Development. 2000; 71(3):543-562.10.1111/1467-8624.00164 [PubMed: 10953923]

Maes HM, Woodard CE, Murrelle L, Meyer JM, Silberg JL, Hewitt JK, Rutter M, Simonoff E, Pickles A, Carbonneau R, Neale MC, Eaves LJ. Tobacco, alcohol and drug use in eight- to sixteen-yearold twins: The Virginia Twin Study of Adolescent Behavioral Development. Journal of Studies on Alcohol and Drugs. 1999; 60:293-305. 
Marcos M, Pastor I, de la Calle C, Barrio-Real L, Laso F, González-Sarmiento R. Cannabinoid receptor 1 gene is associated with alcohol dependence. Alcoholism Clinical and Experimental Research. 2011; 36(2):267-271.10.1111/j.1530-0277.2011.01623.x

Marx BP, Brailey K, Proctor SP, Macdonald HZ, Graefe AC, et al. Association of time since deployment, combat intensity, and posttraumatic stress symptoms with neuropsychological outcomes following Iraq war deployment. Archives of General Psychiatry. 2009; 66(9):996-1004. [PubMed: 19736356]

Masten, AS. Resilience in individual development: Successful adaptation despite risk and adversity. In: Wang, MC.; Gordon, EW., editors. Educational resilience in inner-city America: Challenges and prospects. Erlbaum; Hillsdale, NJ: 1994.

Mattiko MJ, Olmsted KL, Brown JM, Bray RM. Alcohol use and negative consequences among active duty military personnel. Addictive Behaviors. 2011; 36(6):608-614.10.1016/j.addbeh.2011.01.023 [PubMed: 21376475]

McDonald SD, Beckham JC, Morey RA, Calhoun PS. The validity and diagnostic efficiency of the Davidson Trauma Scale in military veterans who have served since September 11, 2001. Journal of Anxiety disorders. 2009; 23:247-255. [PubMed: 18783913]

McCarty CA, Ebel BE, Garrison MM, DiGiuseppe DL, Christakis DA, Rivara FP. Continuity of binge and harmful drinking from late adolescence to early adulthood. Pediatrics. $2004 ; 114: 714-719$. [PubMed: 15342844]

Mc LeardMann CA, Powell TM, Smith TC, Bell MR, Smith B, Boyko EJ, Hoge CW. Risk factors associated with suicide in current and former US military personnel. JAMA. 2010; 310(5):496506.10.1001/jama.2013.65164

McLeod DS, Koenen KC, Meyer JM, Lyons MJ, Eisen S, True W, Goldberg J. Genetic and environmental influences on the relationship among combat exposure, posttraumatic stress disorder symptoms, and alcohol use. Journal of Traumatic Stress. 2001; 14(2):259-275. [PubMed: 11469155]

Mensch BS, Kandel DB. Underreporting of Substance Use in a National Longitudinal Youth Cohort. Public Opinion Quarterly. 1988; 52:100-124.

Midanik LT, Clark WB. The demographic distribution of U.S. drinking patterns in 1990: Description and trends from 1984. American Journal of Public Health. 1994; 84:1218-1222. [PubMed: 8059875]

Miller WR. Researching the spiritual dimensions of alcohol and other drug problems. Addiction. 2002; 93(7):979-990.10.1046/j.1360-0443.1998.9379793.x [PubMed: 9744129]

Milliken CS, Auchterlonie JL, Hoge CW. Longitudinal assessment of mental health problems among active and reserve component soldiers returning from the Iraq War. Journal of the American Medical Association. 2007; 298:2141-2148. [PubMed: 18000197]

Moon DG, Jackson KM, Hecht ML. Family risk and resiliency factors, substance use, and the drug resistance process in adolescence. Drug Education. 2000; 30(4):373-198. [PubMed: 11221574]

Naimi TS, Brewer RD, Mokdad A, Clark D, Serdula MK, Marks JS. Binge drinking among US adults. Journal of the American Medical Association. 2003; 289(1):70-75.10.1001/jama.289.1.70 [PubMed: 12503979]

Nolen-Hoeksema S. Gender differences in risk factors and consequences for alcohol use and problems. Clinical Psychology Review. 2004; 24:981-1010.10.1016/j.cpr.2004.08.003 [PubMed: 15533281]

Notario-Pacheco B, Solera-Martinez M, Serrano-Parra M, Bartolomé-Gutiérrez R, Garcia-Campayo J, Martinez-Vizcaino V. Reliability and validity of the Spanish version of the 10-item ConnorDavidson Resilience Scale (10-item CD-RISC) in young adults. Health and Quailty of Life Outcomes. 2011; 9:1-6. 10.1186/ 1477-7525-9-63.

Reid C, Fiellin DA, O'Connor PG. Hazardous and Harmful Alcohol Consumption in Primary Care. Archives Internal Medicine. 1999; 159:1681-1689.

Rhem, KT. Alcohol Abuse costs DOD dearly. American Forces Press Service; 2000. Retrieved from http://usmilitary.about.com/library/milinfo/milarticles/blalcohol.htm

Richards MS, Goldberg J, Rodin MB, Anderson RJ. Alcohol consumption and problem drinking in white male veterans and nonveterans. American Journal of Public Health. 1989; 79(8):1011-1015. [PubMed: 2751015] 
Richardson G. The metatheory of resilience and resiliency. Journal of Clinical Psychology. 2002; 58:307-321.10.1002/jclp.10020 [PubMed: 11836712]

Riddle MS, Tribble DR, Putnam SD, Mostafa M, Brown TR, Letizia A, Armstrong AW, Sanders JW. Past trends and current status of self-reported incidence and impact of disease and nonbattle injury in military operations in Southwest Asia and the Middle East. American Journal of Public Health. 2008; 98(12):2199-206. [PubMed: 18923114]

Rutter M. Resilience in the Face of Adversity: Protective Factors and Resistance to Psychiatric Disorder. British Journal of Psychiatry. 1985; 147:598-611. [PubMed: 3830321]

Rutter M. Psychosocial resilience and protective mechanisms. American Journal of Orthopsychiatry. 1987; 57(3):316-331.10.1111/j.1939-0025.1987.tb03541.x [PubMed: 3303954]

Rutter, M. Developing concepts in developmental psychopathology. In: Hudziak, JJ., editor. Developmental psychopathology and wellness: Genetic and environmental influences. Washington, DC: American Psychiatric Publishing; 2008. p. 3-22.

Saunders JB, Aasland OG, Babor TF, de la Puente JR, Grant M. Development of the alcohol use disorders screening Test (AUDIT). WHO collaborative project on early detection of persons with harmful alcohol consumption II. Addiction. 1993; 88:791-804. [PubMed: 8329970]

Segal, ZV.; Williams, JMG.; Teasdale, JD. Mindfulnessbased cognitive therapy for depression. New York: Guilford Press; 2002.

Scali J, Gandubert C, Ritchie K, Soulier M, Ancelin ML, et al. Measuring Resilience in Adult Women Using the 10-Item Connor-Davidson Resilience Scale (CD-RISC). Role of Trauma Exposure and Anxiety Disorders. PLoS ONE. 2012; 7(6):e39879.10.1371/journal.pone.0039879 [PubMed: 22768152]

Scherrer JF, Xian H, Lyons MJ, et al. Posttraumatic stress disorder; combat exposure; and nicotine dependence, alcohol dependence, and major depression in male twins. Comprehensive Psychiatry. 2008; 49(3):297-304. 10.1016/ j.comppsych. 2007.11.001. [PubMed: 18396190]

Schlenger WE, Kulka RA, Fairbank JA, Hough RL, Jordan BK, Marmar CR, Weiss DS. The psychological risks of Vietnam: the NVVRS perspective. Journal of Traumatic Stress. 2007; 20(4): 467-479. [PubMed: 17721970]

Schulenberg, J.; Maggs, JL. A developmental perspective on alcohol and other drug use during adolescence and the transition to young adulthood. 2001. Retrieved from www.monitoringthefuture.org/pubs/occpapers/occ51.pdf

Scott JC, Pietrzak RH, Mattocks K, Southwick SM, Brandt C, Haskell S. Gender differences in the correlates of hazardous drinking among Iraq and Afghanistan veterans. Drug and Alcohol Dependence. 2012; 127(1-3):15-22. 10.1016/ j.drugalcdep.2012.06.003. [PubMed: 22770463]

Seal KH, Bertenthal D, Miner CR, Sen S, Marmar C. Bringing the war back home. Mental health disorders among 103-788 US Veterans returning from Iraq and Afghanistan seen at Department of Veterans Affairs Facilities. Archives of Internal Medicine. 2007; 167(5):476-482.10.1001/ archinte.167.5.476 [PubMed: 17353495]

Seal KH, Cohen G, Waldrop A, Cohen BE, Maquen S, Ren L. Substance use disorders in Iraq and Afghanistan veterans in VA healthcare, 2001-2010: Implications for screening, diagnosis and treatment. Drug and Alcohol Dependence. 2011; 116(1-3):93-101. [PubMed: 21277712]

Seligman ME, Csikszentmihalyi M. Positive psychology: An introduction. American Psychologist. 2000; 55(1):5-14. [PubMed: 11392865]

Shipherd JC, Stafford J, Tanner LR. Predicting alcohol and drug abuse in Persian Gulf War veterans: what role do PTSD symptoms play? Addictive Behaviors. 2005; 30(3):595-599. [PubMed: 15718078]

Smith, C.; Lizotte, AJ.; Thornberry, TP.; Krohn, MD. Resilient youth: Identifying factors that prevent high-risk youth from engaging in delinquency and drug use. In: Hagan, J., editor. Delinquency and disrepute in the life course. Greenwich, CT: JAI Press; 1995. p. 217-247.

Stahre MA, Brewer RD, Fonesca VP, Naimi TS. Binge drinking among U.S. active-duty military personnel. American Journal of Preventative Medicine. 2009; 36(3):208-217.

Ungar M. Resilience across cultures. British Journal of Social Work. 2008; 38 (2):218-235.10.1093/ bjsw/bcl343 
U.S. Department of Health and Human Services, National Institutes of Health, National Institute on Alcohol Abuse and Alcoholism. Helping Patients Who Drink Too Much: A Clinician's Guide. 2005. Updated 2005 Edition. Retrieved from http://pubs.niaaa.nih.gov/publications/Practitioner/ CliniciansGuide2005/guide.pdf

Vogt DS, Proctor SP, King DW, King LA, Vasterling JJ. Validation of scales from the Deployment Risk and Resilience Inventory in a sample of Operation Iraqi Freedom veterans. Assessment. 2008; 15(4):391-403.10.1177/1073191108316030 [PubMed: 18436857]

Volpicelli J, Balaraman G, Hahn J, Wallace H, Bux D. The role of uncontrollable trauma in the development of PTSD and alcohol addiction. Alcohol Research and Health. 1999; 23:84-291.

Wagnild GM, Young HM. Development and psychometric evaluation of the resilience scale. Journal of Nursing Measurement. 1993; 1(2):165-178. [PubMed: 7850498]

Wagnild G, Young HM. Resilience among older women. Journal of Nursing Scholarship. 2007; 22(4): 252-255.10.1111/j.1547-5069.1990.tb00224.x

Wang L, Shi Z, Zhang Y, Zhang Z. Psychometric properties of the 10-item Connor-Davidson Resilience Scale in Chinese earthquake victims. Psychiatry and Clinical Neurosciences. 2010; 64:499-504.10.1111/j.1440-1819.2010.02130.x [PubMed: 20923429]

Watkins, S.; Sherk, J. Who serves in the U.S. military? The demographics of enlisted troops and officers. Center for Data Analysis Report\#08-05. 2008. Retrieved from Heritage Foundation website: http://www.heritage.org/research/reports/2008/08/who-serves-in-the-us-military-thedemographics-of-enlisted-troops-and-officers

Wilk JE, Bliese PD, Kin PY, Thomas JL, McGurk D, Hoge CW. Relationship of combat experiences to alcohol misuse among U.S. soldiers returning from the Iraq war. Drug and Alcohol Dependence. 2010; 108(1-2):115-121.10.1016/j.drugalcdep.2009.12.003 [PubMed: 20060237]

Xian H, Chantarujikapong SI, Scherrer JF, et al. Genetic and environmental influences on posttraumatic stress disorder, alcohol and drug dependence in twin pairs. Drug and Alcohol Dependence. 2000; 61(1):95-102. http://dx.doi.org/10.1016/S0376-8716(00)00127-7. [PubMed: 11064187]

Young ST, Hansen CJ, Gibson RL, Ryan MA. Risky alcohol use, age at onset of drinking, and adverse childhood experiences in young men entering the US Marine Corps. Archives of Pediatrics and Adolescent Medicine. 2006; 160(12):1207-14.10.1001/archpedi.160.12.1207 [PubMed: 17146017]

Youssef NA, Green KT, Beckham JC, Elbogen EB. A 3-year longitudinal study examining the effect of resilience on suicidality in veterans. Annals of Clinical Psychiatry. 2013; 25(1):59-66. [PubMed: 23376871]

Youssef NA, Green KT, Dedert EA, Hertzberg JS, Calhoun PS, Dennis MF, Beckham JC. MidAtlantic Mental Illness Research, Education and Clinical Center Workgroup. Exploration of the influence of childhood trauma, combat exposure, and the resilience construct on depression and suicidal ideation among U.S. Iraq/Afghanistan era military personnel and veterans. Archives of Suicide Research. 2013; 17(2):106-122.10.1080/13811118.2013.776445 [PubMed: 23614484]

Zautra, AJ.; Hall, JS.; Murray, KE. Resilience: A new definition of health for people and communities. In: Reich, JW.; Zautra, AJ.; Hall, JS., editors. Handbook of adult resilience. New York: Guilford; 2010. p. 3-34.

Ziedonis D, Hitsman B, Beckham JC, Zvolensky M, Adler LE, Audrain-McGovern J, Breslau N, Brown RA, George TP, Williams J, Calhoun PS, Riley WT. Tobacco use and Cessation in psychiatric disorders: National Institute of Mental Health report. Nicotine and Tobacco Research. 2008; 10(12):1691-715. [PubMed: 19023823]

Zimmerman MA, Arunkumar R. Resiliency research: Implications for schools and policy. Social Policy Report. 1994; 8:1-18. 


\section{Highlights}

- Models controlled for history of alcohol abuse and demographic and traumarelated variables.

- Baseline resilience, age, and history of alcohol abuse were related to alcohol misuse at follow-up.

- Change in resilience and gender was related to alcohol misuse at follow-up.

- Age, combat, self-reported history of alcohol abuse, and baseline resilience was related alcohol misuse at follow-up.

- Resilience is an important factor for protection against alcohol misuse overtime. 


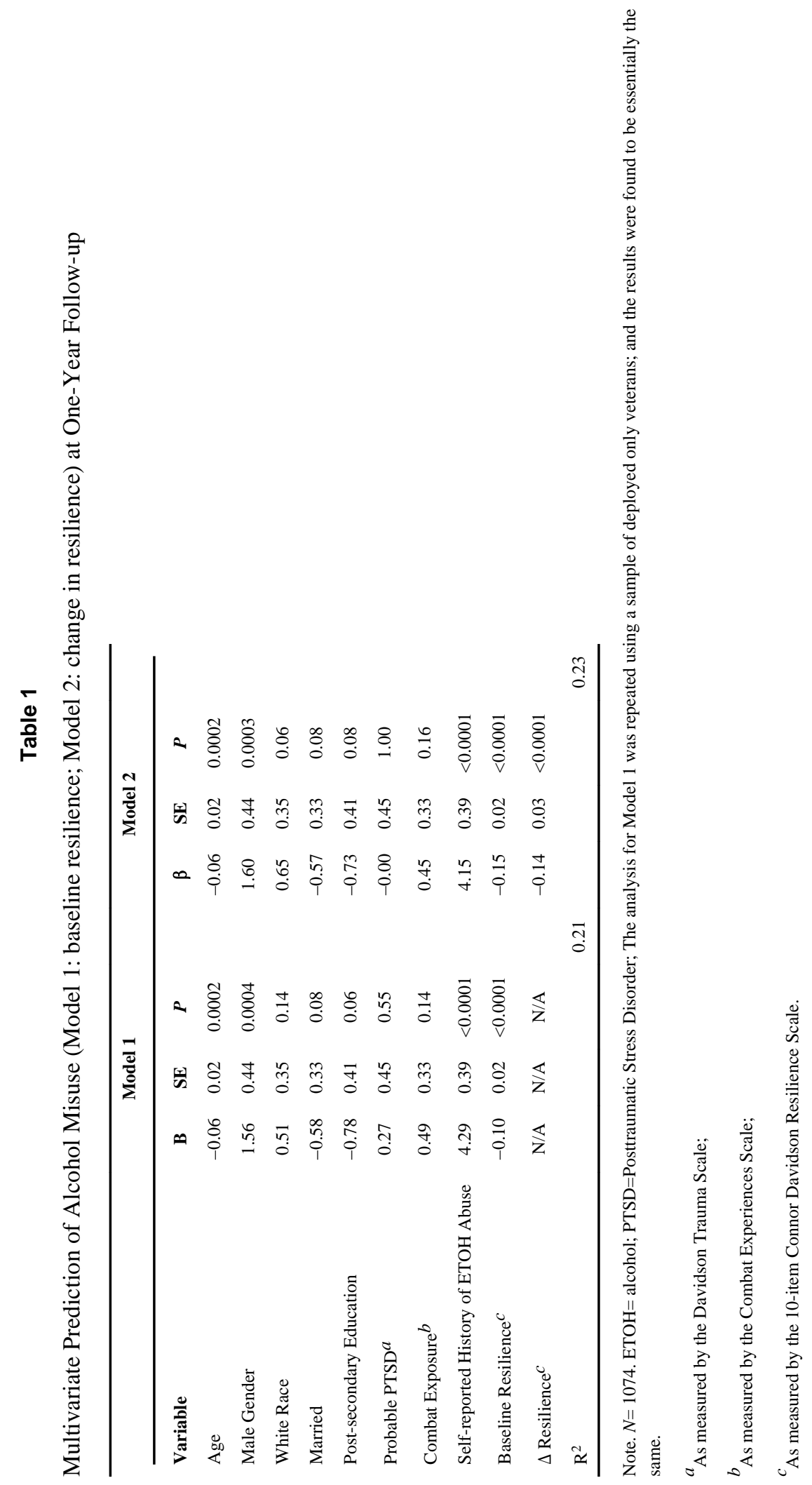




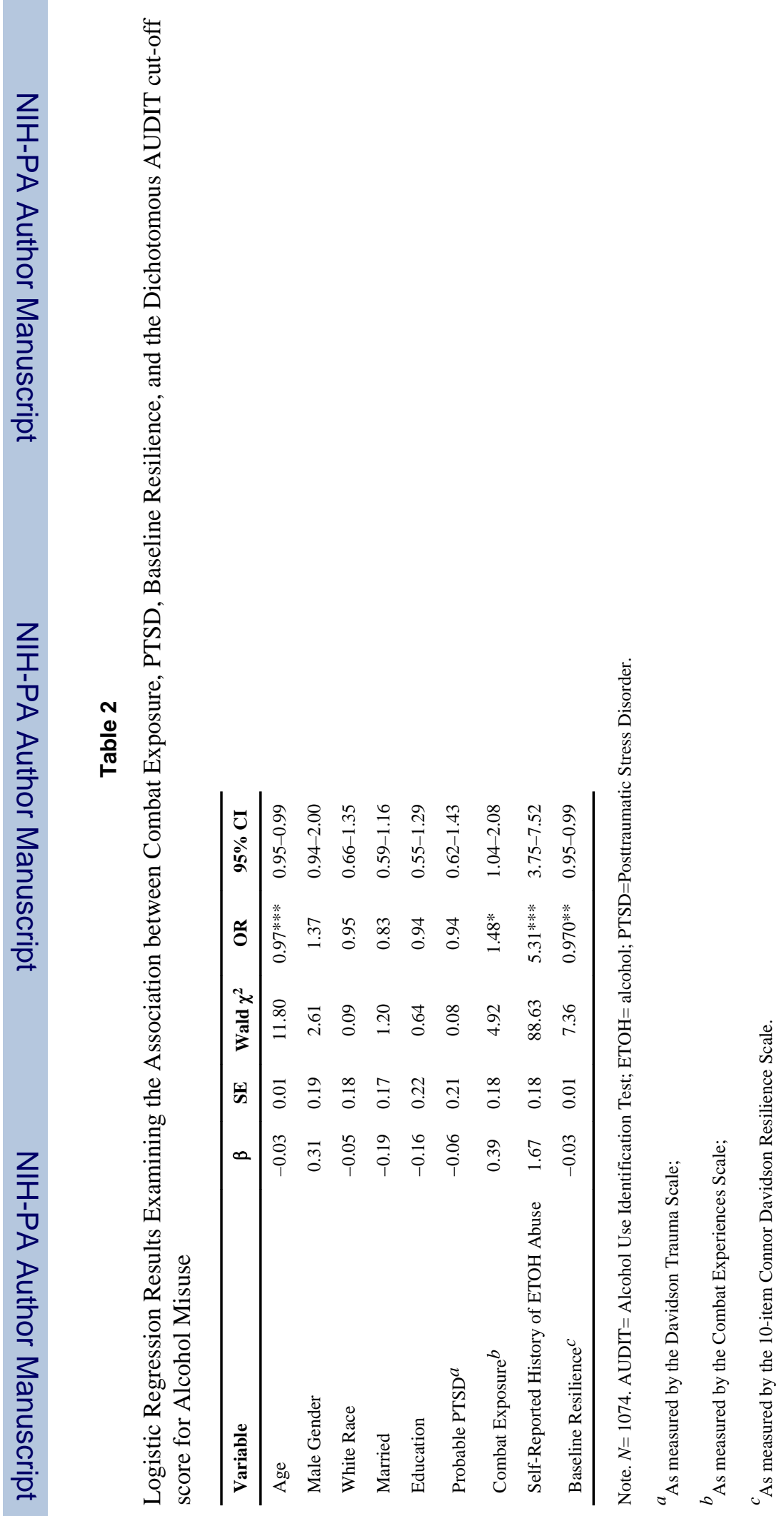

